\title{
SUNFLOWER BIOMASS DISTRIBUTION AND SEED YIELD IN SALINE SOIL OF MEXICO HIGHLANDS
}

Escalante- Estrada, J.A.* and Rodríguez- González, M.T.

Postgrado en Botánica, Campus Montecillo, Colegio de Postgraduados, Montecillo, Méx. 56230, México

Received: March 18, 2010

Accepted: May 28, 2010

SUMMARY

Soil salinity is a worldwide problem. The aim of this study was to evaluate biomass production and partition in the organs of sunflower under a gradient of salinity in the soil. The Victoria sunflower was sown on 15 June 2007 at a density of 100,000 plants $\mathrm{ha}^{-1}$ in Montecillo Mex. $\left(19^{\circ} \mathrm{N}, 48^{\circ} \mathrm{W}\right.$ and 2,400 $\mathrm{m})$. The area has an arid climate (less dry), an annual rainfall of $558.5 \mathrm{~mm}$, and an average temperature of $14.6^{\circ} \mathrm{C}$. Based on soil analysis, three areas were used as the treatments, each having 4 replicates. These were: high salinity (EC $11 \mathrm{dS} \mathrm{m}^{-1}, \mathrm{HS}$ ), medium salinity (EC $7 \mathrm{dS} \mathrm{m}^{-1}, \mathrm{MS}$ ), and low salinity (EC $5 \mathrm{dS}$ $\mathrm{m}^{-1}$, HS). Crop emergence occurred eight days after sowing (DAS), anthesis (R5) 80 DAS, and physiological maturity (R9) 130 DAS. Dry matter accumulation (\%) in plant organs, total biomass, yield and survival all decreased with increasing salinity, whereas DM distribution did not. The highest biomass, yield and survival were found in the LS treatment $\left(1055,102 \mathrm{~g} \mathrm{~m}^{-2}\right.$, and $100 \%)$, while the lowest values of these parameters were recorded in the area with HS $\left(312,29 \mathrm{~g} \mathrm{~m}^{-2}\right.$, and $\left.60 \%\right)$, respectively. The greatest dry matter accumulation was observed in the stem, followed by the receptacle, seeds and leaves. The harvest index and the filled capitulum index were not affected by salinity. In conclusion, biomass accumulation, yield and survival of sunflower decreased with increasing soil salinity. The phenology and biomass distribution in the plant organs were not affected by salinity.

Key words: Helianthus annuus L., phenology, climate elements, dry matter, distribution, harvest index

\section{INTRODUCTION}

Salinity is one of the main factors limiting world crop production (Tanji, 1990). In Mexico, this problem occurs in arid irrigated areas on the coast and in closed basins, as is the case of Lake Texcoco, which covers an area of 26,760 ha (Fernández, 1990). Thus, studies on the knowledge of the physiological variables affected by salinity could provide a guideline for developing strategies that lead to a reduc-

* Corresponding author: e-mail: jasee@colpos.mx; mate@colpos.mx 
tion of the damage caused by this factor. Salinity inhibits plant growth due to water deficit, ion toxicity, nutritional imbalance or a combination of these factors (Cramer and Bowman, 1984). The effect manifests itself in the inhibition of leaf expansion and biomass production (Leidi et al., 1991). Argentel et al. (2008) suggest that the magnitude of the effect of salinity depends on the phenological stage in which it occurs. In wheat the flowering stage is the most sensitive. Seed number is the yield component most affected by salinity. In contrast, Villa-Castorena et al. (2006) report that in pepper (Capsicum annuum L.) early growth stages are more sensitive. To increase crop production in saline regions, a number of strategies have been proposed, one of which is the use of salt tolerant species. This has led physiologists to focus their studies on trying to understand the mechanisms that determine the difference between cultivars tolerant and sensitive to this factor (Epstein, 1985). When sunflower (Helianthus annuus L.) considered tolerant of salinity (Maas, 1990) was grown in a hydroponic system, the growth and transpiration rate decreased with salinity (Escalante, 1995). Also, Slama and Bouzaidi (1978) have shown that electrical conductivity of 3.7 to $5.1 \mathrm{mmhos}^{-1}$ reduces the height of sunflowers but not seed yields. Studies on biomass distribution in plant organs and the yield of sunflower in saline soils are limited, although recent studies have reported a very variable yield possibly due to the mosaic of salt content in soil (Escalante and Rodriguez, 1998). The aim of this study was to determine the effect of soil salinity on sunflower phenology and biomass production, accumulation and distribution in plant organs and seed yield.

\section{MATERIALS AND METHODS}

The study was carried out in Montecillo, Mexico $\left(19^{\circ} \mathrm{N}, 48^{\circ} \mathrm{W}, 2,400 \mathrm{~m}\right.$ altitude) in an area measuring approximately 1.5 ha. The soil at the site is salinesodium (Huez et al., 1989) as a mosaic with variable soil characteristics. The climate is BS1 (semiarid, mean annual of rainfall $558.5 \mathrm{~mm}$, and a temperature of $14.6^{\circ} \mathrm{C}$ ). The vegetation is mainly halophytic salt grass (Distichlis spicata L.) and "romerito" (Suaeda nigra L.) (Gutierrez and Ortiz, 1999). Some areas have been improved for agriculture through washes and manure applications among other things. Rainfed agriculture and irrigation on a smaller scale are used to grow maize, alone or in association with beans and squash. The yields are low, but the advantage is getting a crop in infertile soil (Fernandez, 1990). Victoria sunflower was sown on 15 June 2007 at a density of 100,000 plants ha-1 with 100-100-0 NPK. Based on soil analysis (six samples taken from each replicate before planting at 30 $\mathrm{cm}$ depth), three areas measuring $100 \mathrm{~m}^{2}$ each were selected. The areas had the following characteristics:
a) low salinity ( $\mathrm{pH} 7.3, \mathrm{EC} 5 \mathrm{dS} \mathrm{m}^{-1}, \mathrm{Na}^{+}$exchangeable $1.6 \mathrm{cmol} \mathrm{kg}^{-1}$ ),
b) medium salinity ( $\mathrm{pH} 7.8, \mathrm{EC} 7 \mathrm{dS} \mathrm{m}^{-1}, \mathrm{Na}^{+}$interchangeable $3.0 \mathrm{cmol} \mathrm{kg}^{-1}$ ) and
c) high salinity ( $\mathrm{pH} 8, \mathrm{EC} 11 \mathrm{dS} \mathrm{m}^{-1}, \mathrm{Na}^{+}$interchangeable $9.5 \mathrm{cmol} \mathrm{kg}^{-1}$ ). 
Hereafter, the areas will be referred to as LS, MS and HS, respectively. Each area was subdivided into 4 plots (replicates) of $25 \mathrm{~m}^{2}$ each. A section of each plot, 4 $\mathrm{m}^{2}$ in size, was used to record the phenology of the crop (Schneiter and Miller, 1981). The plants were harvested to evaluate: survival rate (\%) (number of emerged plants/population density $\times 100$ ), yield (dry seed weight, $\mathrm{g} \mathrm{m}^{-2}$ ), total biomass (dry weight, $\mathrm{g} \mathrm{m}^{-2}$ ), DM accumulation $\left(\mathrm{g} \mathrm{m}^{-2}\right)$ and distribution (\%) in plant organs, and the filled capitulum index $(\mathrm{FCI}$, (seed DM/receptacle DM) $\times 100)$. Analysis of variance by SAS was applied to these variables. Monthly mean maximum temperature ( $\mathrm{T}$ max), monthly mean minimum temperature ( $\mathrm{T} \mathrm{min}$ ), photosynthetic active radiation (PAR, monthly mean), monthly amount of rainfall (PP), and monthly amount of evaporation (Evap) were also recorded.

\section{RESULTS AND DISCUSSION}

\section{Phenology and climate elements}

At all salinity levels, sunflower phenological stages happened at a similar time. From the elements of climate presented in Table 1, we can see that the highest $\mathrm{T}$ max value $\left(30^{\circ} \mathrm{C}\right)$ was recorded during crop emergence (VE, 8 days after planting, DAP) along with a $\mathrm{T}$ min value of $9.2^{\circ} \mathrm{C}$, an RFA mean of $8.8 \mathrm{MJ} \mathrm{m}^{-2} \mathrm{day}^{-1}$, and 102 $\mathrm{mm}$ and $131 \mathrm{~mm}$ of PP and Evap, respectively.

Table 1: Monthly mean maximum and minimum temperatures $\left({ }^{\circ} \mathrm{C}\right)$, photosynthetic active radiation $(\mathrm{PAR})$, and monthly rainfall $(\mathrm{PP}, \mathrm{mm})$ and evaporation (Evap, $\mathrm{mm}$ ) during development of sunflower (Helianthus annuus L.). Montecillo, Mex. 2007

\begin{tabular}{lccccc}
\hline \multirow{2}{*}{ Month } & $\mathrm{T} \max \left({ }^{\circ} \mathrm{C}\right)$ & $\mathrm{T} \mathrm{min}\left({ }^{\circ} \mathrm{C}\right)$ & $\mathrm{PAR}$ & $\mathrm{PP}(\mathrm{mm})$ & Evap $(\mathrm{mm})$ \\
\cline { 2 - 6 } & \multicolumn{5}{c}{$\mathrm{MJ} \mathrm{m}^{-2}$ day $^{-1}$} \\
\hline June & 30.0 & 9.2 & 8.8 & 102 & 131 \\
July & 28.0 & 9.2 & 8.5 & 125 & 104 \\
August & 28.0 & 8.9 & 8.6 & 78 & 131 \\
September & 26.0 & 9.7 & 7.3 & 141 & 102 \\
October & 28.2 & 5.4 & 8.7 & 25 & 121 \\
Mean & 28.5 & 8.1 & 8.5 & $\Sigma 482$ & $\Sigma 768$ \\
\hline
\end{tabular}

At the beginning of anthesis (R5, $80 \mathrm{DAP})$ these values were lower $\left(28^{\circ} \mathrm{C} \mathrm{T} \max\right.$, $\mathrm{T}$ min $8.9^{\circ} \mathrm{C}$, RFA $8.6 \mathrm{MJ} \mathrm{m}^{-2} \mathrm{day}^{-1}$, PP $78 \mathrm{~mm}$ ), while evaporation was similar (131 $\mathrm{mm}$ ). From R5 to R9, or physiological maturity (reproductive stage of 50 days duration), and especially at the final stage of seed filling, there was a decrease in $\mathrm{T}$ min to $5.4^{\circ} \mathrm{C}$, with PP at $25 \mathrm{~mm}$ and Evap at $121 \mathrm{~mm}$. This temperature can be considered within the appropriate range for sunflower development (Vranceanu, 1977; Macchia et al., 1985). The PAR values were close to those reported by Rawson et al. (1984) with $9.5 \mathrm{MJ} \mathrm{m}^{-2}$ day $^{-1}$ for the start of the reproductive stage (R1, Schneiter and Miller, 1981), which in this case was 32 DAS. Moreover, during most of the 
period of growth, the sunflowers were under severe water stress, since evaporation exceeded rainfall (Table 1), thus limiting the production of biomass and yield (Table 2).

\section{Biomass, yield and survival}

Biomass, yield and survival of sunflower decreased in relation to salinity. The highest biomass production, yield and survival were obtained in the LS treatment ( $5 \mathrm{dS} \mathrm{m}^{-1}$ ) with $1055 \mathrm{~g} \mathrm{~m}^{-2}, 102 \mathrm{~g} \mathrm{~m}^{-2}$ and 100\%, followed by MS (7 $\mathrm{dS} \mathrm{m}^{-1}$ ) with $750 \mathrm{~g} \mathrm{~m}^{-2}, 63 \mathrm{~g} \mathrm{~m}^{-2}$ and $90 \%$ and HS ( $11 \mathrm{dS} \mathrm{m}^{-1}$ ) with $311 \mathrm{~g} \mathrm{~m}^{-2}, 29 \mathrm{~g} \mathrm{~m}^{-2}$ and $62 \%$ (Table 2). The biomass production and yield variability was related to changes in population density and survival generated by soil salinity. This suggests that besides of low population density, the effect of "mitigating" or reduction of damage by salinity that it happens in dense populations is lowest (Francois, 1982). Finally, given the highest yield (1055 $\mathrm{g} \mathrm{m}^{-2}$ ) and the amount of available rainfall (482 $\mathrm{mm}$ ) for crop growth, the obtained yield is located in the category "favorable" for production in no saline soils (Ortegon et al., 1993).

Table 2: Biomass $\left(\mathrm{g} \mathrm{m}^{-2}\right.$ ) and its distribution in the organs of sunflower (Helianthus annuus L.) as a function of salinity. Montecillo, Mex. Summer 2007

\begin{tabular}{lccccc}
\hline \multirow{2}{*}{ Salinity } & Stem & Leaves & Receptacle & Seed & Total \\
\cline { 2 - 6 } & $\left(\mathrm{g} \mathrm{m}^{-2}\right)$ & $\left(\mathrm{g} \mathrm{m}^{-2}\right)$ & $\left(\mathrm{g} \mathrm{m}^{-2}\right)$ & $\left(\mathrm{g} \mathrm{m}^{-2}\right)$ & $\left(\mathrm{g} \mathrm{m}^{-2}\right)$ \\
\hline Low & $594 \mathrm{a}$ & $99 \mathrm{a}$ & $260 \mathrm{a}$ & $102 \mathrm{a}$ & $1055 \mathrm{a}$ \\
Medium & $440 \mathrm{ab}$ & $78 \mathrm{~b}$ & $170 \mathrm{~b}$ & $63 \mathrm{~b}$ & $750 \mathrm{ab}$ \\
High & $164 \mathrm{c}$ & $39 \mathrm{c}$ & $80 \mathrm{c}$ & $29 \mathrm{c}$ & $311 \mathrm{c}$ \\
Mean & 399 & 72 & 170 & 65 & 705 \\
Prob.F & $\star$ & $\star$ & $\star *$ & $\star *$ & $\star \star$ \\
Tukey 5\% & 332 & 20 & 85 & 31 & 464 \\
\hline
\end{tabular}

${ }^{\star}, \star \star \mathrm{P}>0.01,0.05$, respectively

Table 3: Survival (SOB, \%), harvest index (\%) and filled capitulum index (FCI,\%) of sunflower (Helianthus annuus L.) as a function of salinity. Montecillo, Mex. Summer 2007

\begin{tabular}{lccc}
\hline \multirow{2}{*}{ Salinity } & SOB & Harvest index & FCl \\
\cline { 2 - 4 } & $(\%)$ & $(\%)$ & $(\%)$ \\
\hline Low & $100 \mathrm{a}$ & 10 & 41 \\
Medium & $92 \mathrm{a}$ & 10 & 39 \\
High & $60 \mathrm{a}$ & 10 & 38 \\
Mean & 84 & 10 & 39 \\
Prob.F & $*$ & $\mathrm{NS}$ & $\mathrm{NS}$ \\
Tukey 5\% & 18 & --- & --- \\
\hline
\end{tabular}

*,** $\mathrm{P}>0.01,0.05$, respectively; NS - no significant differences $(P>0.05)$

\section{Biomass accumulation and distribution in the organs of sunflower}

In Table 2, which presents DM accumulation in sunflower organs, it can be observed that this parameter decreased with increasing salinity. This accumulation was greater in the stem, followed by receptacle, leaves, and seeds (yield). In con- 
trast, in the case of DM distribution (\%), no significant changes were observed. Mean distribution was 56\%, 25\%, 10\% and 9\% for stem, receptacle, leaves and seeds (yield), respectively, with the last figure representing the harvest index. A similar trend was observed for the filling capitulum index (Table 3). These trends are similar to those generated by other kinds of stress such as nitrogen deficiency or high intraspecific competition caused by dense populations (Vega et al., 2001), suggesting that DM accumulation in plant organs is mainly determined by changes in the environment and that DM distribution is determined by the genotype and, to a smaller degree, by changes in the environment. Moreover, harvest index values observed under salinity are lower than those reported under other stress conditions such as the ones mentioned above.

\section{CONCLUSIONS}

Biomass accumulation in the organs, yield and survival of sunflower decreased with increasing salinity. The phenology and biomass distribution in sunflower plant organs are not affected by salinity.

\section{REFERENCES}

Argentel, L., López, R., Fonseca, I., Girón, R. y González, L.M., 2008. Efecto de la salinidad sobre la fenología, los componentes del rendimiento y su relación con la tolerancia varietal a la salinidad en trigo (Triticum aestivum y $T$. durum). Cultrop 29(3): 53-57.

Cramer, G.R. and Bowman, D.C., 1994. Cell elongation control under stress conditions. In: M. Pessarakli (Ed.), Handbook of plant and crop stress. Marcel Decker New York. NY, USA, pp. 303-320.

Escalante Estrada, J.A., 1995. Nitrógeno y salinidad y sus efectos sobre el crecimiento del girasol. Terra 13 (3): 376-384.

Escalante Estrada, J.A.S. y Rodríguez, G.M.T., 1998. Producción de girasol (Helianthus annuus L.) en suelos salinos de Montecillo Méx. Efecto de NPK. $2^{\text {nd }}$ Congreso estatal de investigación en educación, ciencia y tecnología. Chapingo, Méx. 26-27 de mayo.

Epstein, E., 1985. Salt tolerant crops: origin, development and prospects of the concept. Plant Soil 89: 187-198.

Fernández, G.R., 1990. Algunas experiencias y proposiciones sobre recuperación de suelos con problemas de sales en México. Terra 8(2): 226-240.

Francois, L.E., 1982. Narrow row cotton (Gossypium hirsutum L.) under saline conditions. Irrig. Sci. 3: 149-156.

Gutiérrez, C. Ma. del C. y Ortiz, C.S., 1999. Origen y evolución de los suelos del exlago de Texcoco, México. Agrociencia 33: 199-208.

Huez, L.M.A., Ortega, M.E., Ramírez, C.A. y Rone, P.J.L., 1989. Caracterización de algunas propiedades fisico-químicas de los suelos y espesores subyacentes del predio Montecillo. Agrociencia 78: 231-247.

Leidi, E.O., Silberbush, M. and Lips, S.H., 1991. Wheat growth as affected by nitrogen type, pH and salinity. I. Biomass production and mineral composition. J. Plant Nutr. 14: 235-246.

Macchia, M., Benvenuti, A. and Baldanzi, M., 1985. Temperature requirements during germination in sunflower. In: Proc. $11^{\text {th }}$ Int. Sunflower Conf. 10-13 March 1985. Mar del Plata Argentina. Int. Sunflower Assoc. Toowoomba, Australia, pp. 93-97.

Maas, E.V., 1990. Crop Salt tolerance. In: Tanji, K.K. (Ed.), Amer. Soc. Civil Eng., ASCE. Manuals and Reports on Engineering Practice No.71. ASCE. New York, USA, pp. 1990.

Ortegón, M.A.S., A. Escobedo, A.M., Loera, G.J., Díaz, F.A. y Rosales, R.E., 1993. El Girasol. Editorial Trillas México, pp.192. 
Rawson, H.M., Dunstone, R.L., Long, M.J. and Begg, J.E., 1984. Canopy development, light interception and seed production in sunflower as influenced by temperature and rediation. Aust. J. Plant Physiol. 11: 255-265.

Schneiter, A. and Miller, J.F., 1981. Description of sunflower growth stages. Crop Sci. 21: 901903.

Slama, F. and Bouzaidi, A., 1978. Effect of salinity on growth and production of sunflower varieties. Sunflower Newsletter, Sunflower Association 2(4): 13-17.

Tanji, K.K., 1990. Nature and extent of agricultural salinity. Agricultural salinity assesment and management, K.K. Tanji (Ed.). Amer. Soc. Civil Eng., ASCE. Manuals and Reports on Engineering Practice No.71. ASCE. New York, USA, pp. 1-17.

Vega, R.M., Escalante-Estrada, J.A., Sánchez, G.P., Ramírez, A.C. y Cuenca, A.E., 2001. Asignación de biomasa y rendimiento de girasol con relación a nitrógeno y densidad de población. Terra 19(1): 75-81.

Villa-Castorena, M., Catalán Valencia, E.A., Inzunza-Ibarra, M.A. e Sánchez Cohen, I., 2006. La fertilización nitrogenada y la salinidad del suelo afectan la transpiración y absorción de nutrimentos en plantas de chile. Terra Latinoamericana 24(3): 391-399.

Vranceanu, A.V., 1977. El girasol; traducción de A. Guerrero. Mundi Prensa, Madrid, pp. 181213 y $219-237$.

\title{
DISTRIBUCION DE BIOMASA Y RENDIMIENTO DE GIRASOL EN SUELOS SALINOS DEL ALTIPLANO DE MEXICO
}

\section{RESUMEN}

La salinidad del suelo es un problema mundial. El objetivo de este estudio fue evaluar la producción de biomasa y la partición en los órganos de girasol en un gradiente de salinidad. El girasol cultivar Victoria se sembró el 15 de junio de 2007, a la densidad de 100 mil plantas ha ${ }^{-1}$ en Montecillo Méx. ( $19^{\circ} \mathrm{N}$, $48^{\circ} \mathrm{W}$ y $2.400 \mathrm{~m}$ ), de clima árido (el menos seco), con precipitación anual de $558,5 \mathrm{~mm}$ y temperatura media de $14,6^{\circ} \mathrm{C}$. Los tratamientos de salinidad fueron: alta (CE $11 \mathrm{dS} \mathrm{m}^{-1}$, HS), media (CE $7 \mathrm{dS} \mathrm{m}^{-1}$, MS) y baja (CE $5 \mathrm{dS} \mathrm{m}^{-}$ ${ }^{1}$,LS) con 4 repeticiones. La emergencia del cultivo ocurrió a los 8 días de la siembra (DAS), la antesis (R5) a 80 DAS y la madurez fisiológica (R9) a 130 DAS. En los órganos de la planta, la acumulación de materia seca (AMS), pero no la distribución (\%), la biomasa total, el rendimiento y la supervivencia disminuyeron con la salinidad. La mayor biomasa, rendimiento y sobrevivencia fue de 1.055 y $102 \mathrm{~g} \mathrm{~m}^{-2}$ y $100 \%$ en LS, y el más bajo de 312 y $29 \mathrm{~g} \mathrm{~m}^{-2}$ y $60 \%$ en HS, respectivamente. La mayor AMS se observó en tallo, seguido del receptáculo, semillas y hojas. El índice de cosecha y el índice de capítulo no mostraron cambios. En conclusión, la acumulación de biomasa, rendimiento y sobrevivencia de girasol son afectados por la salinidad. La fenología y distribución de biomasa en los órganos de girasol no son afectados.

\section{DISTRIBUTION BIOMASSE ET RENDEMENT DE TOURNESOL DANS DES SOLS SALINS DU PLATEAU DU MEXIQUE}

\author{
RÉSUMÉ
}

La salinité des sols est un problème mondial. L'objectif de cette étude était d'évaluer la production de biomasse et la partition dans les organes de tournesol dans un gradient de salinité. Le cultivar de tournesol a été semé Vic- 
toria le 15 Juin 2007, la densité de plantes 100 mille ha- ${ }^{1}$ dans Montecillo, Mex. $\left(19^{\circ} \mathrm{N}, 48^{\circ} \mathrm{W}\right.$ et $2400 \mathrm{~m}$ ), du climat aride (moins sèche), avec une pluviométrie annuelle de 558,5 $\mathrm{mm}$ et la température moyenne de $14,6^{\circ} \mathrm{C}$. Salinité traitements étaient les suivants: élevé (CE $\left.11 \mathrm{dS} \mathrm{m}^{-1}, \mathrm{SH}\right)$, moyen (CE $7 \mathrm{dS} \mathrm{m}$ 1 , MS) et faible (CE $\left.5 \mathrm{dS} \mathrm{m}^{-1}, \mathrm{LS}\right)$ avec 4 répétitions. La levée se produit à 8 jours après le semis (DAS), l'anthèse (R5) à 80 DAS et la maturité physiologique (R9) à 130 DAS. Dans les organes de la plante accumulation de matière sèche (AMS), mais pas la distribution (\%), la biomasse totale, le rendement et la diminution de la survie avec la salinité. Le plus grand rendement de la biomasse et de la survie a été de 1055 et $102 \mathrm{~g} \mathrm{~m}^{-2}$ et $100 \%$ en LS, et le plus bas de 312 et $29 \mathrm{~g} \mathrm{~m}^{-2}$ et $60 \%$ en $\mathrm{SH}$, respectivement. La plupart des AMS a été observée dans les cellules souches, suivi par le récipient, les graines et les feuilles. L'indice de récolte et de l'indice chapitre a montré aucun changement. En conclusion, l'accumulation de la biomasse, le rendement du tournesol et la survie sont affectés par la salinité. La phénologie et la distribution de la biomasse dans les organes de tournesol ne sont pas affectés. 
